\title{
Criança na escola? Programa de Formação Integral da Criança
}

\author{
Geraldo di Giovanni * \\ Aparecida Neri de Souza*
}

\begin{abstract}
RESUMO: Este artigo analisa uma política pública que foi implementada em São Paulo, Brasil, entre os anos de 1986 e 1993. Este programa público, chamado Profic - Programa de Formação Integral da Criança -, procurou estender o tempo de permanência das crianças pobres na escola e expandir as condições para seu melhor desempenho na aprendizagem. Os autores escolheram uma abordagem incrementalista e usaram conceitos clássicos da análise de políticas, tais como atores, policy community, policy network, partizan mutual adjustment, entre outros. Ao mesmo tempo tentaram considerar as condições políticas que envolveram, então, esse processo de policy making.
\end{abstract}

Palavras-chave: Política educacional - São Paulo, formação integral, Estado e educação, educação - policy making, educação - política focalizada

\section{Introdução}

A perspectiva que será adotada para a análise do Profic será a de análise de processo. Isso significa que o sucesso ou o insucesso de uma política não será considerado como acerto ou erro, como pro-

\footnotetext{
* Professor do Instituto de Economia da Unicamp.

** Professora do Departamento de Ciências Sociais Aplicadas à Educação, Faculdade de Educação, Unicamp.
} 
duto de circunstâncias favoráveis ou desfavoráveis, mas como resultado da interação de vários fatores (ação dos atores, conjunturas políticas, constrangimentos econômicos, elementos culturais etc.) de natureza dinâmica, que produzem uma configuração final no processo de policy making. Tal posição não-relativista tem conseqüências sobre os planos analítico, descritivo e, até mesmo, prescritivo, uma vez que pode revelar - sem prejuízo do rigor metodológico - situações, evidências relevantes para o julgamento de casos específicos e também para generalizações. Não se trata pois, de um estudo sob a ótica do rational problem solving que, individualizando fracassos e sucessos, poderia conduzir a uma simplificação de um processo extremamente rico e complexo.

A avaliação do Profic - Programa de Formação Integral da Criança - apresentou dificuldades. Em primeiro lugar, salta aos olhos a inexistência de dados quantitativos gerais e sistematizados, bem como a pouca representatividade dos dados parciais produzidos. Isso se deve ao fato de o Programa, a partir do seu segundo ano de existência, nunca ter sido uma atividade considerada como substantiva nas ações da Secretaria de Educação do Estado de São Paulo. Acresçase a isso o fato de que, pelas suas próprias características formais e de execução, cada unidade do Programa acabou por adquirir um modo particular de atuação, o que, de certa maneira, chocou-se com a cultura vigente na Secretaria de homogeneização das atividades no interior da rede de ensino.

Rejeitado inicialmente pela rede estadual de ensino, o Profic conseguiu manter-se até 1993, com oscilações e descontinuidades, graças à militância de alguns grupos no interior da administração central da Secretaria de Educação do Estado e de participantes do Programa na rede de ensino. Tais grupos - que se constituíam em uma espécie de policy partizans - conseguiram desenvolver no curso dos anos uma espécie de lobby que pressionava com maior ou menor intensidade, dependendo sempre de sua capacidade de pressionar o sistema de decisões daquela secretaria.

Outra dificuldade advém do fato de que a avaliação do Profic no interior da Secretaria de Educação é extremamente desigual, polarizada e, freqüentemente, apaixonada. De certa forma, isso se reflete na qualidade dos dados e informações produzidas por parte dos grupos e das pessoas contrárias ao Programa, como também por parte de seus sempre ardorosos defensores. 
Apesar dessas dificuldades, a escolha do Profic como objeto de análise é justificada por algumas de suas características. Inicialmente por ter sido, no caso brasileiro, a primeira experiência em educação integral que se utilizou da parceria como uma estratégia explícita e deliberada para o aproveitamento de recursos preexistentes. Especialmente nos primeiros anos de vigência do programa, a cooperação com as Prefeituras Municipais e com as entidades assistenciais foi decisiva. Ao contrário de outras experiências vivenciadas no Brasil - como o Centro Educacional "Carneiro Ribeiro" (Escola Parque), na Bahia (final dos anos 50); os Ginásios Vocacionais, em São Paulo (década de 1960); os Centros Integrados de Educação Pública (Cieps), no Rio de Janeiro, em 1982; e os Centros de Atenção Integral à Criança e ao Adolescente (Ciacs), programa federal implantado em vários estados brasileiros a partir de $1991^{1}$-, o Profic buscou deliberadamente parceiros no chamado terceiro setor ${ }^{2}$ e no nível mais descentralizado do poder público: o município. Outro fato que justifica o estudo do Profic reside exatamente na forma encontrada para a utilização dos recursos disponíveis: muito cedo, na sua implantação, foi banida a idéia de construção de prédios, salas de aula e congêneres.

Ademais, o Profic foi idealizado como um projeto de Governo, envolvendo mais de uma Secretaria de Estado (Saúde, Promoção Social, Trabalho, Cultura, Esportes e Turismo), o que o diferenciou - como concepção e não como realização - de projetos precedentes ou contemporâneos.

Outra característica de interesse foi o caráter voluntário das adesões ao Programa, que se distanciou por esse traço de outras iniciativas da Secretaria de Educação. E, como critério decisivo de seleção, registre-se o número de 503.238 crianças atendidas no ano de 1988 , o que equivale a $9,11 \%$ dos alunos matriculados nas escolas no estado de São Paulo, sejam públicas ou privadas, em qualquer nível de atendimento. ${ }^{3}$

A inserção do Profic nas atividades da Secretaria foi, no mínimo, inusitada. Em 1986, no final do Governo Franco Montoro, ocorreu uma mudança no Secretariado. Indicado pelo governador, assumiu o professor José Aristodemo Pinotti, ex-reitor da Universidade Estadual de Campinas (Unicamp), que maturara um projeto de atendimento integral da criança e do adolescente, anteriormente à sua posse. Apoiado num pequeno grupo de educadores e técnicos, ao assumir, o novo Secretário já dispunha da primeira versão do projeto Profic. 
O caráter inusitado do Profic advém do fato de que ele representou uma contratendência em relação às concepções dominantes e aos cânones vigentes na formulação de projetos similares, embora tivesse sido elaborado por educadores e houvesse consenso na área da educação sobre a necessidade de expansão do tempo diário de escolarização. Diferia e divergia, também, dos pressupostos teóricos, metodológicos e, mesmo, ideológicos que informavam a maioria dos atores organizados na formulação das políticas educacionais no estado. Essas diferenciações podem ser atribuídas, de um lado, ao fato de não se prender à generalizada obsessão universalista vigente à época no campo da formulação das políticas sociais no Brasil, e, de outro, ao ponto de vista dos processos decisórios, por desconhecer a exigência da forma bottom/up de forte presença na cultura política brasileira no momento em que o país se redemocratizava. Mais do que na proposta concreta de ação, o potencial conflitivo do Profic residia nesses pressupostos.

O Profic existiu de 1986 a 1993. Nesse período, passaram pela Secretaria de Educação sete Secretários, ${ }^{4}$ cada qual portador de um projeto específico de política educacional para o estado de São Paulo. O Profic sobreviveu modificando-se e tendo algumas de suas atividades mimetizadas pela estrutura da Secretaria. Como não poderia deixar de ser, mudaram os atores e transfiguraram-se a forma, o conteúdo e o sentido de suas ações. Seus resultados, muito diferentes daqueles imaginados na proposição inicial, refletem a complexidade natural do processo de implementação de uma política pública e oferecem algumas lições, especialmente as relativas ao caráter incremental dos processos de policy making.

\section{Caracterização do Programa de Formação Integral da Criança (Profic)}

Objetivos, pressupostos e mecanismos

Nos anos que precederam o Profic, as taxas de evasão e repetência incidiam sobre mais de $30 \%$ dos alunos das séries iniciais da rede de ensino estadual de São Paulo (Durhan 1990). Alguns diag- 
nósticos que procuraram explicar esses números, além de outros indicadores da situação educacional do estado, apontavam para uma série de fatores que poderiam ser divididos entre internos ao sistema educacional e externos a ele. No primeiro caso, apontavam-se os baixos salários, a baixa qualidade da formação do professor, o excesso de alunos nas salas de aula, a ausência de condições de infra-estrutura, a inadequação curricular etc. como elementos importantes naquela configuração. No caso dos fatores externos, a crescente pauperização da população escolar apareceu como fator predominante. Tal pauperização expressava-se num conjunto de condições adversas para a realização dos processos de ensino e aprendizagem, as quais iam desde a inexistência de um ambiente familiar propício à sua realização continuada até razões socioeconômicas de natureza prática, que afastariam o aluno da escola.

A proposta do Profic, como veremos, levava em consideração principalmente este último aspecto. Se a escola era vista, na concepção corrente, como a instituição que tinha a finalidade de "socialização daquela parcela do saber sistematizado que constitui o indispensável à formação e exercício da cidadania" (Ande 1986a, p. 6), o novo programa se propunha ir além da função de instrução, agregando a proteção como uma missão institucional paralela. Assim, prescrevia que,

antes de mais nada, é necessário redefinir o papel da escola, transformando-a de instrumento dedicado apenas à instrução em instituição também protetora, que tenha sob sua responsabilidade não só o ensino, mas, de igual maneira, o cuidado da infância que Ihe é confiada. (São Paulo, 1986b, p. 73)

A função de proteção, vinculada à escola, ganhou, para os idealizadores do Profic, um sentido lato. Ou seja, a criança estaria protegida da violência, do desamparo circunstancial, da doença, da fome e da pobreza. Como a literatura existente e a crítica sobre o Profic apontam à exaustão (e como assumem seus idealizadores), este não foi um projeto criado pela nem no interior da Secretaria de Educação (Ferretti 1991). De onde vieram essas idéias? Elaboradas por um grupo de educadores e técnicos ligados à Unicamp, a primeira versão da proposta já estava pronta quando da posse do Secretário Pinotti, em 
maio de 1986. A literatura especializada atribui à concepção do Profic uma origem fundada em duas vertentes: de um lado, estaria identificada uma "aproximação mais que casual" (Ferretti 1991, p. 12) com programas voltados para a área da saúde, como os de Medicina Comunitária e de Atenção Primária à Saúde; de outro lado, a vertente seria o conjunto de teorias de comunidades oriundas da sociologia funcionalista norte-americana.

Assim sendo, foram formuladas críticas de caráter teórico e ideológico. A crítica opera por meio de um silogismo: se existe um parentesco teórico e ideológico entre o Profic e os programas de Medicina Comunitária e Atenção Integral à Saúde, tais como foram preconizados pelas Organizações Mundial e Panamericana de Saúde, logo, estariam intocadas as raízes políticas e socioeconômicas da exclusão social. A perspectiva da sociologia funcionalista também elidiria com esses aspectos. Na verdade, o que está em jogo na maior parte das críticas $^{5}$ é a questão da exclusão social, tal como ocorre nas sociedades capitalistas.

Evidentemente, a matriz teórica que embasou os idealizadores do Profic era totalmente outra. Pensado como um programa emergencial, na primeira versão, de fato, o Profic idealizava as condições e as possibilidades de sua realização. Por isso mesmo foi taxado, em alguns momentos com uma boa dose de razão, de romântico. A idéia de uma escola protegida e protetora pouco tinha a ver com a realidade gritante da rede de ensino escolar brasileira e paulista. A escola redentora e protetora idealizada no momento da apresentação do Programa chocava-se com as idéias dominantes no "campo" da educação. Mais que isso, contrastava de modo muito forte com os trabaIhos de pesquisa que lhe serviram de base informativa (Fecamp 1985), curiosamente apenas citados nas duas versões do projeto e nunca utilizados pelos analistas, fossem favoráveis ou contrários à proposta do Profic.

Embora o Profic tivesse sido fundamentado no estudo da Fecamp (1985), Fundação Economia de Campinas, ${ }^{6}$ ele não recomendava as formas e estratégias de implantação dos programas de educação integral, mas fornecia uma extensa bateria de informações e algumas linhas de ações que justificariam a adoção das políticas preconizadas. O estudo também não indicava a participação de órgãos e entidades não governamentais. 
Este trabalho teve como pontos de partida algumas afirmações e sugestões que podem ser resumidas no que se segue:

- a democratização das oportunidades educacionais se dá no acesso à escola e na possibilidade de permanência do aluno na escola e na igualdade de oportunidades;

- educação igual para todos significa a consideração de formas diferenciadas de atendimento educacional;

- uma proposta educacional que incorpora a desigualdade e reconhece a heterogeneidade social de sua clientela integra também a assistência social como um de seus componentes destinados a possibilitar um quadro pedagógico e social mais favorável;

- os aspectos que dizem respeito diretamente ao aproveitamento escolar podem ser resumidos em carência cultural generalizada, baixo nível de informação e processo urbano de expulsão das populações de baixa renda das áreas de maior disponibilidade de equipamentos e serviços urbanos essenciais. (Fecamp 1985, p. 2)

Perante essas constatações, o estudo procurava formular um desenho de intervenção do Estado onde a escola se colocasse como "ponto de agregação das manifestações socioculturais locais, a par da necessária integração com equipamentos de saúde, promoção social, lazer" (Fecamp 1985, p. 2).

Assim sendo, os subsídios fornecidos à Secretaria de Educação visavam

caracterizar áreas prioritárias de atendimento que se caracterizariam como áreas de atendimento emergencial, não como experiências-piloto; identificar preliminarmente a população escolar que necessita de atendimento diferenciado; e desenvolver estudos básicos para definição do tipo de atendimento diferenciado previsto. (Fecamp 1985, p. 8)

Propunha-se então uma atuação em duas linhas: no que diz respeito à intervenção na rede de ensino fundamental em funcionamento, a Secretaria de Educação do Estado deveria, nas escolas em que predominassem alunos carentes, instituir o ensino em período integral (opcional) e que 
se integrassem nesse esforço demais serviços públicos das áreas sociais, especialmente saúde, esportes e cultura. Quanto à expansão da participação de alunos da rede de ensino estadual, além das medidas já apontadas, o estudo prescrevia uma integração das creches e das pré-escolas à rede de ensino fundamental, com a finalidade de unificar 0 atendimento infantil na faixa de 0 a 14 anos (Fecamp 1985).

Certamente, soluções desse tipo implicariam a formulação de uma proposta de governo, não restrita apenas a um de seus órgãos, uma vez que existiam exigências de articulação com postos e centros de saúde, centros esportivos, bibliotecas públicas etc. Além das atividades convencionais de ensino fundamental, haveria a adição de outras, tal como a introdução de um período de atividades extra-aulas para práticas de esportes, lazer, cultura e reforço escolar. Também deveriam ser incorporados a assistência social e o encaminhamento das crianças aos serviços públicos de saúde, o fornecimento de material escolar, transporte e alimentação. $O$ estudo da Fecamp procurou ainda dimensionar os investimentos de capital necessários, que se traduziam, basicamente, na construção de módulos de integração de serviços em torno da escola, como unidade central.

Tal proposta pode ser qualificada como um exemplo de política residual, na medida em que propõe uma ação de suplementação por parte do Estado, realizando uma espécie de teste de meios permitido pelo conjunto de informações disponíveis. A presença de ações de caráter assistencialista vem justificada, curiosamente, numa perspectiva não-assistencialista.

As ações assistencialistas (inevitáveis, de resto) passam a ser incorporadas à proposta educacional, de forma a atingir toda a clientela da escola, numa perspectiva não mais de ajuda circunstancial à criança: trata-se de buscar um reordenamento nas ações assistencialistas e sociais dentro da escola e colocá-las numa perspectiva onde são incorporadas ao processo educativo como tal e de forma a transformá-las em ações mais amplas de política social.

Ainda que voltada ao atendimento à criança, esta proposta educacional tem como referencial a família de baixa renda, suplementando os encargos familiares com as crianças, prestando o necessário suporte em termos de distribuição indireta de renda, ao mesmo tempo em que libera a família da atenção diária à criança, para outras atividades. (Fecamp 1985, p. 13) 
O fato de a adesão ao programa ser voluntária ressalta

um último aspecto a ser levantado, que o novo cotidiano da criança não prevê o seu confinamento no espaço da escola, mas, pelo contrário, reforça sua vivência cultural na cidade propiciando a compreensão do significado do uso coletivo dos equipamentos públicos. (Fecamp 1985, p. 14)

A primeira versão do Profic, apresentada como absolutamente preliminar e aberta à discussão no âmbito da Secretaria de Educação do Estado (São Paulo 1986a), faz menção a esse estudo, bem como a seus relatórios parciais. Infelizmente, não existe qualquer aproveitamento dos dados do estudo, que poderiam fundamentar de modo mais técnico e objetivo o conjunto de considerações e proposições, muitas delas, estas sim, utilizadas do estudo da Fecamp. A justificativa e os pressupostos teóricos e metodológicos, formulados dentro de uma retórica psicologista e uma fundamentação sociológica e pedagógica pouco claras e definidas, destoam da qualidade das proposições práticas adotadas (São Paulo 1986a).

A falta das informações constantes desse estudo, bem como a ausência dos dados quantitativos de excelente qualidade nele contidos, "enfraqueceu" a proposta, que foi dada a público de forma tãosomente retórica, abrindo flanco para críticas que severamente a qualificaram de megalomaníaca, improvisada etc.

O caráter assistencialista do projeto, confrontado com os elementos oferecidos por aquele estudo, dada a situação de carência das populações de baixa renda, surge reconhecidamente como inevitável, principalmente dentro de uma proposta concebida como sendo de caráter emergencial, conforme veremos adiante.

Para esclarecer essas considerações, examinaremos os objetivos do Profic:

- a transformação conceitual e prática da escola de ensino fundamental, gradualmente, de instituição dedicada à instrução formal da infância em instituição dedicada à formação integral da criança; 
- a transformação conceitual e prática da pré-escola, gradualmente, de instituição dedicada à preparação para a alfabetização em instituição dedicada à formação integral da criança;

- a ampliação do período de permanência da criança na escola de primeiro grau, em decorrência dessa transformação;

- estabelecimento, de maneira direta ou indireta, de uma rede de pré-escolas no estado, de modo a atender, de maneira integral e integrada, a criança até os seis anos de idade;

- a criação de condições para que o período de permanência da criança na pré-escola possa corresponder ao período de trabalho dos pais;

- a criação de condições para que as mães, especialmente aquelas de classes mais pobres, possam estar presentes junto de seus filhos, amamentando-os, se possível, nos dois primeiros anos de vida da criança;

- a cooperação com entidades públicas e privadas no sentido de encontrar fórmulas para resolver o problema do menor já abandonado. (São Paulo 1986a, p. 76)

Esses objetivos definiram as estratégias diretas (execução de projetos dentro da rede de ensino oficial do estado) e indiretas (convênios com Prefeituras Municipais do estado e entidades assistenciais privadas), persistindo sempre a idéia de integralização do atendimento, com base na extensão de seu tempo e de atividades complementares à instrução. Tais atividades que conformam a atenção integral foram postuladas como sendo: aulas regulares, alimentação, reforço escolar e atividades diversificadas. Além disso, as "ações voltadas para a saúde individual e coletiva" constituiriam uma preocupação constante (Lima 1987, p. 24).

O Profic foi inicialmente articulado em torno de quatro projetos que procuraram dar uma cobertura à criança, desde sua fase anterior à entrada nas instituições de ensino até completar os 14 anos. Tentou definir também uma política de atenção ao menor já em estado de abandono, atendendo crianças "de rua", infratoras ou não.

Os projetos foram:

1. Projeto de formação integral da criança nos dois primeiros anos de vida - Por meio de uma participação indireta da Secretaria de 
Educação, esse projeto visava criar condições institucionais para o cumprimento e o aperfeiçoamento da legislação que obriga empresas a manter creches e berçários. A Secretaria cumpriria um papel de agente articulador de instituições privadas e governamentais com a finalidade de estabelecer essa rede de atenção, voltando-se em especial às formas de organização que facilitassem o aleitamento materno por parte de mães trabalhadoras.

2. Projeto de formação integral do pré-escolar (2 a 6 anos) - 0 ponto fundamental desse projeto era o aumento do tempo de permanência da criança na escola, sempre de acordo com os horários de trabalho dos pais. Além disso, o projeto visava ir além do desenvolvimento intelectual e cognitivo da criança, proporcionando oportunidades para seu desenvolvimento físico, psíquico, social e emocional. A Secretaria teria aqui uma atuação direta, pelo estabelecimento de convênios com as prefeituras e entidades assistenciais privadas.

3. Projeto de formação integral do escolar (7 a 14 anos) - Nesse projeto, o fundamento foi, também, o aumento do tempo de permanência da criança na escola, objetivando um período de oito horas. Não significava um aumento da atividade propriamente escolar, mas um acréscimo de atividades recreativas, artísticas, esportivas e, eventualmente, um reforço de aprendizagem. A característica interessante do projeto é que o tempo de permanência alargado foi proposto como facultativo. Nesse projeto, a participação da Secretaria de Educação seria direta e dar-seia por intermédio da rede de ensino escolar, especialmente das escolas localizadas nos grandes centros urbanos e regiões pobres.

4. Projeto de atendimento ao menor abandonado - Esse projeto não foi definido com clareza. Entende-se de seu esboço que a participação da Secretaria da Educação seria indireta, em colaboração com a Secretaria de Promoção Social, e que especial ênfase seria dada à ampliação e ao aperfeiçoamento da Escola-Oficina, projeto já existente na Secretaria de Educação.

População-alvo, instrumentos de focalização e resultados obtidos

A formulação do Profic sempre foi extremamente genérica, revelando, desde o início, uma grande carência de dados estatísticos 
que auxiliassem no estabelecimento de metas e facilitassem a elaboração de instrumentos de focalização. Entretanto, os documentos preliminares indicam que - pelas redes de ensino estadual e municipais e das entidades assistenciais - se poderiam atingir as crianças situadas em faixas de população de baixa renda, nos grandes centros urbanos e em regiões pobres, nas faixas etárias definidas nos projetos mencionados.

No que se refere à educação infantil para a faixa etária de 2 a 6 anos, de atuação preferencial das prefeituras e entidades assistenciais, pretendiam-se atingir as famílias com renda inferior a três salários mínimos. Entretanto, o projeto não apresentou indicadores, mecanismos ou instrumentos de focalização da população que participaria do Programa. A população infantil paulista com idade de 5 a 6 anos que, teoricamente, deveria estar matriculada numa instituição de educação pré-escolar era, em 1990, de 1.477.182; neste ano, 53\% delas freqüentavam a préescola. $^{7}$

\section{Tabela 1}

População por faixa etária, matrículas iniciais, Profic Estado de São Paulo

$1987-1990$

\begin{tabular}{l|r|r|r|r}
\hline \multicolumn{1}{c}{1987} & \multicolumn{1}{c}{1988} & \multicolumn{1}{c}{1989} & 1990 \\
\hline População 0/6 anos & 4.998 .643 & 5.001 .482 & 5.006 .876 & 5.014 .869 \\
Matrícula pré-escola & 736.349 & 759.029 & $79.690^{\star}$ & 785.331 \\
Matrícula Profic & 194.114 & 242.012 & 76.058 & 61.182 \\
População 7/14 anos & 5.010 .162 & 5.194 .992 & 5.390 .675 & 5.597 .898 \\
Matrícula ensino fundamental & 5.274 .413 & 5.523 .233 & $4.576 .26^{\star}$ & 5.998 .060 \\
Matrícula Profic & 141.418 & 261.226 & 186.972 & 185.534 \\
\hline
\end{tabular}

Fonte: SEE/CIE. Elaboração NEPP/Unicamp, 1994

*Dados referentes somente à rede estadual de ensino

O Projeto de Formação Integral do Escolar na faixa etária de 7 a 14 anos propunha, na primeira versão, que a implantação fosse gradual e discriminada até atingir $15 \%$ da população escolar (cerca de 600 mil alunos), caracterizada como sendo composta por "alunos provenientes de classes de baixa renda". A prioridade deveria ser dada a crianças matriculadas nas quatro primeiras séries do ensino fundamental, com idade entre 7 e 10 anos, residentes nos grandes centros 
urbanos e regiões pobres. A participação seria facultativa e a decisão, da família. A segunda versão, sob o crivo das críticas, não propunha metas precisas.

Embora o Profic tenha sido idealizado como um plano de ação conjunta entre várias secretarias de Estado (Secretaria de Educação, à qual caberia a coordenação das ações, e pelas Secretarias da Promoção, Ação Social, Relações de Trabalho, Cultura, Esportes e Turismo), na prática, com o início das atividades, a Secretaria de Educação reuniria poderes para as iniciativas necessárias, capacidade essa que se consolidaria com as normas editadas posteriormente ao decreto de criação do programa.

$\mathrm{O}$ instrumento jurídico que regulou as relações entre o poder público municipal, as entidades assistenciais e a Secretaria de Educação do Estado foi um modelo de convênio-padrão, que estabelecia as obrigações das partes envolvidas, bastando apenas para sua concretização a manifestação dos interesses das instâncias municipais e assistenciais em participar, sem maiores complicações burocráticas.

Dessa forma, no primeiro ano de vigência do Profic, em 1986, havia 205 unidades participantes do programa, mantidas pelas prefeituras e entidades assistenciais. Foram assinados convênios com 128 prefeituras, atendendo 179.800 crianças $^{8}$ e 102 convênios com entidades assistenciais, atendendo 19.156 menores. A rede de ensino estadual passa a integrar o Profic em 1987 que, implantado inicialmente em 337 escolas, atingiu 335.532 crianças. A partir daí foi crescente sua participação, chegando a predominar sobre os outros setores.

As escolas estaduais justificavam sua inserção no Profic, a partir de 1987, pela possibilidade de: "(a) baixar os índices de repetência e evasão escolar; (b) suprir a ausência dos pais que trabalhavam; (c) oferecer enriquecimento curricular; (d) integrar a comunidade à escola" (Mendes Júnior 1991). ${ }^{9}$ A partir de 1989, a Prefeitura Municipal de São Paulo retirou-se do Programa, o que alterou profundamente a quantidade de crianças nele inserida. Entretanto, a participação dos alunos estaduais continuava aumentando: de 1987 a 1990 cresceu cerca de $230 \%$, chegando, em 1990, a 150 mil alunos.

Esses dados nos servem para demonstrar que o Profic tinha um bom potencial de aceitação, mesmo nos primeiros seis meses de sua 
existência. ${ }^{10}$ Como vimos, esses números ampliaram-se no ano seguinte, o qual pode ser considerado o ponto de maior presença do Programa, até mesmo porque as dotações orçamentárias já estavam asseguradas pelo Governo que concluía seu mandato.

Segundo Mendes Júnior (1991), em 1989, 93\% dos alunos matriculados no ensino fundamental participantes do Profic residiam nos grandes centros urbanos e suas famílias, que possuíam renda de até três salários mínimos, eram

\begin{abstract}
desestruturadas, em geral com pai ausente. A saúde das crianças foi classificada como precária, sendo mais freqüentes casos de verminoses, desnutrição, cáries, deficiência visual, problemas emocionais e falta de higiene. (op. cit, p.7)
\end{abstract}

Embora esse programa tenha atingido, no seu auge, cerca de $10 \%$ dos alunos matriculados no ensino fundamental, poder-se-ia afirmar que atingiu apenas parcialmente os objetivos propostos. Os projetos Formação integral da criança nos dois primeiros anos de vida e Atendimento ao menor abandonado não foram implantados. ${ }^{11}$ Os demais, Formação integral do pré-escolar e Formação integral do escolar, foram implementados num conjunto significativo de municípios e de escolas no estado de São Paulo, compreendendo atividades diversificadas - desde reforço escolar até atividades esportivas e artísticas - e atendendo crianças pertencentes aos segmentos sociais de baixa renda familiar, conforme depoimentos recolhidos com as equipes técnicas e diretoras das escolas. Não havia instrumentos precisos de seleção das crianças participantes; via de regra, as professoras indicavam seus alunos a partir de critérios aleatórios e muitas vezes subjetivos. ${ }^{12}$

\title{
Custos e características do financiamento
}

Os dados relativos ao financiamento do Profic, disponíveis até agora, ${ }^{13}$ devem ser examinados com cuidado, uma vez que são compostos por informações de fontes diferentes, havendo o risco de dupla contagem ou mesmo de omissão. 
Os recursos do Programa originaram-se de três grandes fontes:

1') Tesouro do Estado;

2ª) Quota Estadual do Salário-Educação; ${ }^{14}$

$\left.3^{a}\right)$ recursos próprios e do Governo Federal.

A partir de 1988, o repasse de recursos para o Profic passou a ser vinculado às rubricas de despesa: merenda escolar (75\%), material de consumo (25\%) e contratação de professores, no caso de convênios com prefeituras e entidades assistenciais. Quanto às escolas da rede estadual de ensino, os recursos cobriam apenas a merenda escolar e o material de consumo.

Os gastos referentes a pessoal, com recursos provenientes do Tesouro do Estado, não constam de nenhum dos relatórios analisados, embora haja informações de que cerca de $3 / 4$ dos gastos da Secretaria de Educação do Estado tivessem sido com o magistério. Os professores envolvidos no programa eram contratados pela Secretaria e pagos com recursos do Tesouro do Estado. ${ }^{15}$

A merenda escolar já estava municipalizada quando o Profic foi implementado. Portanto, tanto os alimentos como os recursos humanos (merendeira) deveriam ser fornecidos pela prefeitura. A Secretaria de Educação contribuía com pequeno auxílio, proveniente de verba QESE - Quota Estadual do Salário-Educação - para complementação da merenda escolar.

\section{Tabela 2}

Recursos estaduais destinados ao Profic

Estado de São Paulo

$1986-1988$

\begin{tabular}{rrrrrr}
\hline NCz $\$$ a preços de 1989 (1) & & & \\
\hline & Rede estadual & Prefeituras & Entidades assistenciais & \multicolumn{1}{c}{ Total } & Total em US\$ (2) \\
\hline 1986 & 2.494 .971 & 3.391 .138 & 2.647 .406 & 8.533 .515 & 3.014 .176 \\
1987 & 14.108 .334 & 8.577 .449 & 9.935 .688 & 32.621 .471 & 11.522 .433 \\
1988 & 2.409 .028 & 3.504 .774 & 4.105 .979 & 10.019 .781 & 3.539 .149 \\
\hline
\end{tabular}

Fonte: Relatório do Profic - 1986/Equipe Técnica Profic - 1987-1988

Elaboração NEPP/Unicamp, 1993

(1) IGP-DI médio estimado 1989 - Conjuntura Econômica

(2) Atualizado para 1992 pelo IGP-DI médio, dólar médio de $92=\operatorname{Cr} \$ 4.516,74$ 


\section{Tabela 3}

Participação do Profic nos recursos da Secretaria de Educação Estado de São Paulo $1986-1988$

\begin{tabular}{c|c|r|r|r}
\hline Cz\$1.000,00 / 88 (1) & \multicolumn{5}{|l}{} \\
\hline ANO/RECURSO & SECRETARIA & PROFIC & US\$ mil (2) & $\%$ \\
1986 & EDUCAÇÃO & & & \\
1987 & 418.836 .972 & 784.518 & 3.035 & 0,2 \\
1988 & 405.905 .878 & 2.999 .014 & 15.041 & 0,7 \\
& 342.663 .579 & 921.156 & 4.620 & 0,3 \\
\hline
\end{tabular}

Fonte: SE/ATPCE. Elaboração NEPP/Unicamp, 1993

(1) IGP-DI médio 87 / 88

(2) Atualizado para 1992 pelo IGP-DI; dólar médio de $92=\operatorname{Cr} \$ 4.516,74$

A queda posterior, em 1988, deve-se ao fato de a nova gestão ter implantado um programa ambicioso, a Jornada única docente e discente, que, além de proporcionar mudanças organizacionais e pedagógicas, mimetizou alguns princípios do Profic, como por exemplo a permanência de 6 horas diárias das crianças no Ciclo Básico. ${ }^{16}$ Mesmo assim, o número de crianças atendidas pelo Profic cresceu, sendo tal crescimento atribuído às mudanças nas suas diretrizes, que seriam menos assistencialistas que no início de sua implementação.

A tabela 4 representa um esforço para estimar os custos per capita para a Secretaria de Educação do Estado, uma vez que não há dados disponíveis nem sobre os orçamentos disponíveis nem sobre os gastos efetivamente realizados pelas prefeituras e entidades assistenciais, oriundos de outras fontes. Em tal estimativa não foram incluídas despesas de pessoal, uma vez que estas estão incluídas nas despesas globais de pessoal da Secretaria. Nesse caso, essas despesas representam cerca de $80 \%$ a $90 \%$ do gasto total da área de educação do governo do estado.

Pelas informações existentes, conforme a tabela 3, pode-se dizer que a participação do Profic nos recursos da Secretaria de Educação não foi de grande monta, possivelmente porque o programa conseguiu mobilizar, em seu proveito, boa parte da infra-estrutura existente nas escolas e nos segmentos interessados da comunidade.

A análise dos Planos de Trabalho Anuais (PTAs) da Secretaria de Educação do Estado dos anos subseqüentes indica um tra- 
tamento diferenciado do Profic. ${ }^{17}$ Esses PTAs são documentos com previsões de destinação de recursos para implementação, ampliação ou manutenção dos programas, ações e projetos da Secretaria. Apenas em 1990 o Profic constava no PTA com rubrica própria e como programa conjunto do Gabinete do Secretário com as Coordenadorias de Ensino (interior e grande São Paulo) e a Disaete (Divisão de supervisão e apoio às escolas técnicas estaduais). Nesse PTA, a fonte de financiamento para a "Manutenção e ampliação do Profic na rede de ensino estadual" era a QESE (Quota Estadual do Salário-Educação).

\section{Tabela 4}

Estimativa de repasse anual per capita, por dependência administrativa, Profic Estado de São Paulo $1986-1988$

\begin{tabular}{r|rrr|rrr|rrr}
\hline & \multicolumn{3}{|c|}{ Escolas Estaduais } & \multicolumn{3}{c|}{ Prefeituras Municipais } & \multicolumn{3}{c}{ Entidades Assistenciais } \\
\hline ano & Alunos & Repasse & Per capita & alunos & Repasse & Per capita & alunos & Repasse & Per capita \\
& & & & & & & & & \\
1986 & 21.363 & 881.263 & 41,25 & 179.880 & 1.197 .803 & 6,66 & 19.156 & 935.105 & 48,82 \\
1987 & 45.638 & 4.983 .285 & 109,19 & 248.552 & 3.029 .689 & 12,19 & 41.342 & 3.509 .441 & 84,89 \\
1988 & 99.392 & 850.906 & 8,56 & 351.698 & 1.238 .941 & 3,52 & 52.427 & 1.450 .292 & 27,66 \\
\hline
\end{tabular}

Fonte: SEE. Elaboração NEPP/Unicamp, 1994

Obs.: Dólar médio a preços de 1992

Excluídos gastos com pessoal

Nos anos subseqüentes, 1991 e 1992, o Profic já não participava do PTA com rubrica própria; entretanto, estava incluso nas ações de "serviços e materiais de suporte às ações do ensino do primeiro grau".

As ações previstas para serem desenvolvidas em 1990 eram: reuniões; simpósios; acompanhamento, controle e avaliação do programa; aquisição de material pedagógico para 356 turmas; prestação de serviços em 233 escolas (previstos nos planos dessas escolas); capacitação de professores; material de consumo e pedagógico. Do conjunto de despesas destinadas ao ensino fundamental (com exceção de pessoal), a participação do Profic era correspondente a $0,62 \%$ do total de despesas previstas para este nível de ensino. 


\section{Quadro 1}

Previsão de despesas com o ensino fundamental

Estado de São Paulo - 1990

\begin{tabular}{l|r}
\hline & \multicolumn{1}{c|}{ Ações } \\
Municipalização do ensino & 2,38 \\
Ciclo Básico/ Jornada Única & 6,49 \\
Redefinição do ensino fundamental & 0,96 \\
Integração escola-comunidade & 0,89 \\
Apoio técnico financeiro/ execução dos planos regionais & 1,41 \\
Serviços e materiais de suporte (*) & 16,16 \\
Assistência nutricional & 28,83 \\
Capacitação docente & 2,39 \\
Recursos físicos & 39,89 \\
Serviços e materiais & 0,58 \\
TOTAL & 100,00 \\
\hline
\end{tabular}

Fonte: SEE/PTA. Elaboração NEPP/Unicamp, 1994

$\left({ }^{\star}\right)$ Profic participava (estava incluso neste item)

Entretanto, se desagregarmos os recursos orçamentários, incluindo pessoal, para esse mesmo ano, verificaremos que estava previsto:

\section{Quadro 2}

Previsão Orçamentária: Estado de São Paulo - 1990

\begin{tabular}{l|r}
\hline Pessoal & $77 \%$ \\
Material de Consumo & $2 \%$ \\
Merenda & $2 \%$ \\
Outros & $11 \%$ \\
Investimentos de capital: & \\
Obras & $7 \%$ \\
Material permanente & $1 \%$ \\
Outros & $0 \%$ \\
Total & $100 \%$ \\
\hline
\end{tabular}

Fonte: SEE/PTA. Elaboração NEPP/Unicamp, 1994

Em 1991, o PTA indicava que haveria recursos para a aquisição de material de consumo e prestação de serviços para 164 mil alunos participantes do Profic; entretanto, não discriminava a quantidade de re- 
cursos financeiros destinados às ações. O mesmo ocorreu em 1992, quando o PTA indicava a continuidade da implementação Profic para 100 mil alunos, "desde que seja comprovado que o programa atinja a população de baixa renda e o Conselho de Escola aprove a existência do programa", mas, mais uma vez, não havia discriminação de recursos financeiros.

Por intermédio dos PTAs percebe-se um claro movimento de interrupção do programa; embora houvesse indicação de ações de sua implementação, não havia alocação de recursos específicos para o desenvolvimento das atividades nem definição dos órgãos responsáveis pela implementação.

\section{A inserção institucional e o esquema de gestão}

A forma de organização institucional adotada inicialmente - programa vinculado a várias Secretarias de Estado, sob a coordenação de uma delas, no mesmo nível hierárquico - foi considerada, já no ano de lançamento, "um problema adicional". O então Secretário da Educação, referindo-se a alguns problemas de implantação de programas do gênero, dizia em documento oficial:

Nossa experiência na Secretaria de Educação do Estado de São Paulo vem demonstrando que inseri-lo [o Programa] nos quadros de organismos públicos constitui uma dificuldade adicional, dada a necessidade de sua fixação em esquemas tradicionais, que precisam ser rompidos para dar espaço a iniciativas mais inovadoras. (...) Na verdade, não é tão importante saber onde será inserido o programa, desde que se articulou um gerenciamento ágil e eficiente mediante a ação coordenada de órgãos públicos municipais, estaduais e federais, sem prejuízo das entidades privadas que quiserem colaborar. (Lima 1989, p. 19)

Essa visão paulatinamente se entranharia nas normas oficiais do Programa que de um esforço de várias Secretarias (como estava previsto inicialmente) se reduziria a um projeto da Secretaria de Educação, sendo as referências à ação de outros órgãos do governo estadual cada 
vez mais vagas e facultativas. ${ }^{18}$ Em documento de 1988, lançado pela Secretaria de Educação, já se dizia que

independentemente de formalização de ações gerais conjuntas, cabe às Unidades Educacionais provocar, fomentar o envolvimento de outras Secretarias, na medida de suas necessidades e do que foi previsto no seu Plano de Trabalho, valendo-se também do apoio das Delegacias de Ensino e Divisões Regionais de Ensino. (Lima 1989, p. 17)

Em 1993, o Secretário Pinotti, ao avaliar esse processo de relação institucional entre as várias secretarias envolvidas com o programa, argumenta que

Uma das coisas que concluí, na ocasião, é que o problema da criança é da Secretaria de Educação. A Secretaria de Educação tem obrigação de liderar os demais programas, não adianta esperar que o programa da criança seja resolvido parcelarmente por várias Secretarias.(Pinotti 1993) ${ }^{19}$

Isso demonstra o potencial de insucesso de programas de cooperação no mesmo nível hierárquico, sem uma coordenação supra-institucional. É possível perceber duas matrizes de relacionamento institucional: a primeira delas estabelece uma relação direta do Gabinete do Secretário com os agentes implementadores do Programa na esfera dos municípios e das entidades assistenciais; a segunda percorre toda a estrutura organizacional da Secretaria até a unidade escolar estadual.

Assim, a primeira matriz de relacionamento institucional pode ser esboçada como sendo:

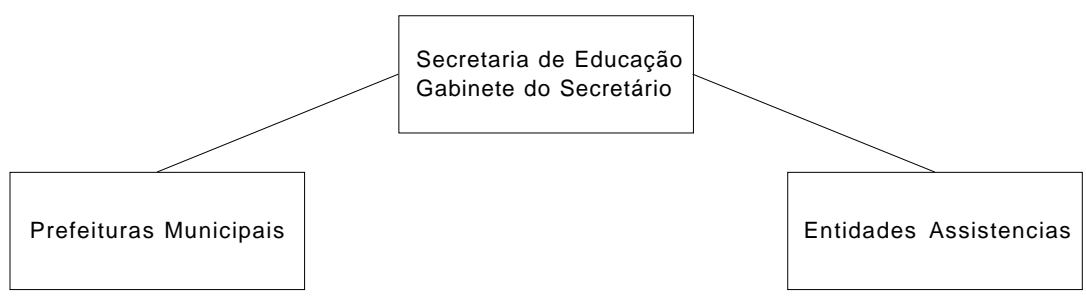


E a segunda:

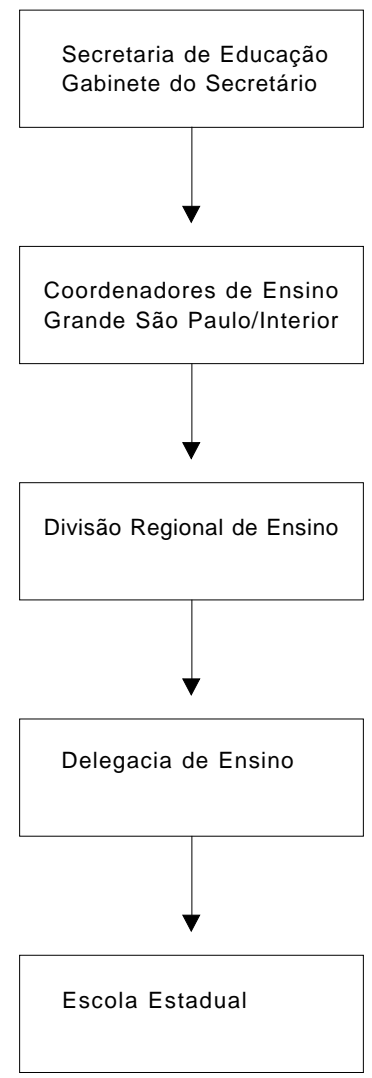

O relacionamento em ambas as matrizes, durante quase toda a vivência do Profic, foi sempre muito centrado na capacidade das unidades educacionais envolvidas de desenvolver seus planos e suas atividades. Cabia à Secretaria, por intermédio da Equipe de coordenação do Profic, o papel de aprovar os projetos, fornecer recursos materiais e, eventualmente, humanos, mas nada indica ter havido disposições impositivas quanto a currículo, conteúdo, tipos de atividade a serem desenvolvidos etc.

$\mathrm{Na}$ visão do Secretário que implantou o Profic 
Outro aspecto, também decorrente da nossa experiência, é que o programa deve ser executado da forma mais descentralizada possível, tanto nos grandes centros quanto nos municípios menores. As autoridades educacionais locais têm demonstrado maior facilidade de compreender e aplicar esse conceito. Não foi surpreendente verificar que em quase todas as cidades do interior de São Paulo várias iniciativas do gênero já haviam sido tomadas, motivadas pelo processo de descentralização e participação do Governo Montoro. Em alguns municípios, os prefeitos, em conjunto com dirigentes da educação e lideranças comunitárias, souberam costurar e integrar essas iniciativas, criando verdadeiros programas municipais de educação integral adaptados às condições locais. (Pinotti 1993) ${ }^{20}$

Visto desse ângulo, parece que a ênfase na descentralização e na desburocratização tinha a vantagem de integrar, sem procedimentos muito complexos, algumas iniciativas locais que, se não se adequavam inicialmente à filosofia do Profic, puderam ser adaptadas na medida em que a Secretaria de Educação passou a financiá-las. ${ }^{21}$

A iniciativa de participação no Profic sempre foi voluntária, tanto para as escolas da rede estadual de ensino, como para as prefeituras e as entidades assistenciais privadas, bastando cumprir alguns requisitos (mínimos, diga-se de passagem), tais como oferecer algumas condições de espaço ocioso e tempo para as atividades e, mais tarde, a partir de 1987, oferecer um plano de trabalho. Em 1988, as exigências foram um pouco ampliadas, ${ }^{22}$ passando a exigir-se, além do plano de atividades, uma previsão de recursos para materiais de consumo, equipamentos, materiais permanentes, alimentação e recursos humanos. Isso não significou nenhuma restrição à autonomia das unidades de ensino: apenas buscou-se introduzir elementos de planejamento e controle do programa (Lima 1989).

Também a estrutura de decisões e controle do Profic revelava muita simplicidade. Na fase inicial (1986 e 1987), manifestado o interesse por parte de uma prefeitura ou de uma entidade assistencial e encaminhada a proposta de convênio pela Delegacia de Ensino, caberia a esta emitir pareceres conclusivos sobre a viabilidade de realização da programação e encaminhar a solicitação à Divisão Regional de Ensino, responsável pelo encaminhamento ao Gabinete do Secretário. No caso das escolas da rede de ensino que manifestassem interesse em participar do Programa, a aprovação era feita tão-somente no nível da Delegacia de Ensino, que deveria, em caso positivo, providenciar a 
imediata implantação do projeto, informando concomitantemente a Divisão Regional de Ensino.

Os níveis de responsabilidade pelo acompanhamento das experiências também eram restritos. Podemos descrevê-los conforme o quadro seguinte:

\section{Quadro 3}

Níveis hierárquicos do Profic

Estado de São Paulo

\begin{tabular}{lll}
\hline NIVEL & ÓRGÃO & RESPONSÁVEL \\
A & Secretaria da Educação & Coordenação Central do Profic \\
B & Divisão Regional de Ensino & Técnico indicado pelo Diretor Regional \\
C & Delegacia de Ensino & Supervisor de Ensino indicado pelo Delegado de Ensino \\
D1 & Escolas Estaduais & Diretor da Escola \\
D2 & Prefeitura Municipal & Secretário Municipal da Educação \\
D3 & Entidade Assistencial & Diretor da entidade \\
\hline
\end{tabular}

Fonte: SEE. Elaboração NEPP/Unicamp, 1993

A partir de 1990, o acompanhamento do Profic deixou de ser realizado diretamente pelo Gabinete do Secretário, por intermédio da equipe de coordenação Central. Esse acompanhamento ficou sob a responsabilidade das Coordenadorias de Ensino da região metropolitana da Grande São Paulo (COGSP) e das do Interior (CEI).

Embora houvesse formalmente responsabilidades definidas, o sistema de controle, acompanhamento e avaliação do programa era bastante frágil. A pesquisa verificou a existência de avaliações do programa apenas no período em que a coordenação estava vinculada ao Gabinete do Secretário. Quando se transferiram para as coordenadorias, essas atividades deixaram de ser realizadas.

A análise de Planos Escolares e pesquisas realizadas sobre o Profic nas escolas evidenciaram uma grande liberdade na seleção de atividades por parte das unidades escolares, prefeituras e entidades assistenciais. ${ }^{23}$ As atividades incluíam vários projetos: horta e jardinagem; recreação; educação artística: oficina de artes cênicas, oficina de música (coral, banda, fanfarra e instrumentos musicais), oficina de artes plásticas; educação física (esportes) e orientação de estudos (utilização de biblioteca e reforço escolar). (Ferretti 1991; São Paulo 1992)

O desempenho do Profic, desde sua implantação até 1993, pode ser avaliado pelas informações da tabela seguinte. 


\section{Tabela 5}

Número de alunos atendidos pelo Profic

Estado de São Paulo

$1986-1993$

\begin{tabular}{|c|c|c|c|c|c|c|c|c|}
\hline \multirow[t]{2}{*}{ ANO } & \multicolumn{2}{|c|}{ REDE ESTADUAL } & \multicolumn{2}{|c|}{ PREFEITURA } & \multicolumn{2}{|c|}{ ENTIDADE ASSISTENCIAL } & \multicolumn{2}{|l|}{ TOTAL } \\
\hline & Quantidade & $\%$ & Quantidade & $\%$ & Quantidade & $\%$ & Quantidade & $\%$ \\
\hline 1986 & 21.363 & 9,6 & 179.880 & 81,6 & 19.156 & 8,6 & 220.379 & 100 \\
\hline 1987 & 45.638 & 13,6 & 248.552 & 74,1 & 41.342 & 12,3 & 335.532 & 100 \\
\hline 1988 & 99.392 & 19,7 & 351.698 & 69,9 & 52.427 & 10,4 & 503.247 & 100 \\
\hline 1989 & 128.725 & 48,9 & 76.246 & 28,9 & 58.059 & 22,1 & 263.030 & 100 \\
\hline 1990 & 150.901 & 61,1 & 88.929 & 36,0 & 6.937 & 2,8 & 246.767 & 100 \\
\hline 1991 & 42.289 (1) & 100,0 & 0 & 0 & 0 & 0 & 42.289 & 100 \\
\hline 1992 & $39.690(2)$ & 100,0 & 0 & 0 & 0 & 0 & 39.690 & 100 \\
\hline 1993 & 34.164 & 100,0 & 0 & 0 & 0 & 0 & 34.164 & 100 \\
\hline
\end{tabular}

Fonte: Profic/SE, CEI/ COGSP. Elaboração NEPP/Unicamp, 1994

(1) A região metropolitana da grande São Paulo

(2) Faltam as DREs Leste e Sul

Dois fatos são evidentes segundo esses dados. Em primeiro lugar, o número crescente dos atendimentos realizados pela rede de ensino estadual e pelas entidades assistenciais. A rede estadual de ensino, que participava no primeiro ano com menos de $10 \%$ dos atendimentos, em 1990 respondeu por $61,1 \%$, ou seja, cresceu no período $536 \%$. Por sua vez, o crescimento da participação das entidades assistenciais foi de apenas $40 \%$, no período de 1986/1989. Várias razões explicam tal situação. A nova administração estadual que assumiu o governo em 1987 priorizou os alunos das escolas estaduais, o que foi reforçado pelas próprias escolas, que viram no programa uma fonte de recursos financeiros para desenvolver projetos próprios.

No que se refere às entidades assistenciais, deve ser acrescentado que, a partir de 1989 , havia um dispositivo constitucional ${ }^{24}$ limitando a possibilidade do governo do estado de São Paulo de firmar convênios com entidades assistenciais para programas educativos, o que representou um outro importante fator de decréscimo desse segmento nas atividades do Profic.

Já no que diz respeito às prefeituras, o crescimento ocorreu até 1988 , verificando-se um aumento de 95\% de 1986 a 1988, para depois cair, em 1989 e anos subseqüentes. Tal queda na participação do município na implementação do Profic foi causada, principalmente, pelas mudanças nas administrações municipais derivadas das eleições. Os novos prefeitos não renovaram ou denunciaram diversos convênios. Somente a não-renovação de convênio da Prefeitura Municipal de São Paulo provocou uma significa- 
tiva queda nos números apresentados. A cidade de São Paulo atendia, em $1988,157.923$ crianças na pré-escola e 97.556 no ensino fundamental, o que significava $51 \%$ de todo o atendimento municipal do Profic.

A implementação do Profic pode, para efeitos de melhor compreensão, ser dividida em três fases: a implantação, propriamente dita, em 1986; a expansão, entre 1987 e 1989; e, finalmente, o declínio e a extinção, de 1990 a dezembro de 1993, quando o Programa foi definitivamente encerrado.

Como pode ser observado na tabela 5 , essas fases revelam algumas características importantes do processo de implementação. Na fase inicial, nota-se uma importante adesão de prefeituras ao Programa, estas responsáveis por $81 \%$ das crianças atendidas. Na fase seguinte verifica-se um incremento da participação da rede estadual de ensino que, em 1990, respondia por $61 \%$ dos atendimentos; embora o número de atendimentos pelas prefeituras tivesse crescido em dados absolutos até 1989.

A participação das entidades assistenciais também cresce até 1989 , quando sofre uma queda brusca. Tal queda foi motivada por uma interpretação do novo texto constitucional do estado de São Paulo que limitava, segundo alguns, ou coibia, segundo outros, o repasse de recursos destinados à educação para entidades privadas.

A tabela 6, que descreve a participação da rede de ensino estadual, das prefeituras e das entidades assistenciais em unidades de Profic, no mesmo período, confirma essa interpretação.

\section{Tabela 6}

Unidades do Profic por Dependência Administrativa Estado de São Paulo

$1987-1993\left(^{*}\right)$

\begin{tabular}{lrrrrrr}
\hline & 1987 & 1988 & 1989 & 1990 & 1992 & 1993 \\
Escolas Estaduais & 415 & 858 & 862 & 921 & $244\left(^{* \star}\right)$ & 450 \\
Escolas Municipais & 218 & 204 & 147 & 132 & 0 & 0 \\
Entidades Assistenciais & 230 & 241 & 293 & 18 & 0 & 0 \\
Total & 863 & 1.303 & 1.302 & 1.071 & 244 & 450 \\
\hline
\end{tabular}

Fonte: SEE/CEI/COGSP. Elaboração NEPP/Unicamp, 1994

${ }^{*}$ ) A pesquisa histórica não contemplou o ano de 1991 devido à falta de dados disponíveis.

$\left.{ }^{* *}\right)$ Dados somente das COGSP

A tabela seguinte procura demonstrar, no período de 1986 a 1989 , a expansão geográfica do Profic, no estado de São Paulo. Essa pene- 
tração foi muito desigual tanto nas diversas regiões do estado como nas regiões administrativas da área metropolitana. Vê-se claramente que, do ponto de vista das prefeituras, as regiões mais atendidas foram: São José do Rio Preto (47 convênios), Ribeirão Preto (35) e Sorocaba e Marília (25). Do ponto de vista das entidades assistenciais, a maior concentração de convênios se deu nas áreas da capital - zona sul (53) e leste (37) - e na região metropolitana de São Paulo - zona oeste (47) e sul (42).

Nos anos de 1991 a 1993, o Profic ficou restrito às escolas estaduais. Os convênios, realizados entre as prefeituras e a Secretaria da Educação, datados de 1986, terminaram em 1991 e não foram renovados. Entretanto, alguns desses municípios mantiveram o programa com recursos exclusivamente municipais, a exemplo de Nova Odessa e Socorro. ${ }^{25}$

Especialmente no que diz respeito às entidades assistenciais, as áreas de maior concentração foram as da região metropolitana da Grande São Paulo, industrializadas, de baixa renda, bem como, no interior, a região de Campinas. Isso, de certa forma, se coaduna com os objetivos propostos pelo Programa. A tabela 8 permite também, para o ano de 1989, avaliar a concentração regional de projetos para a rede de ensino estadual.

\section{Tabela 7}

Convênios novos com prefeituras e entidades assistenciais, por Divisão Regional de Ensino (DRE)

Estado de São Paulo

1986-1989

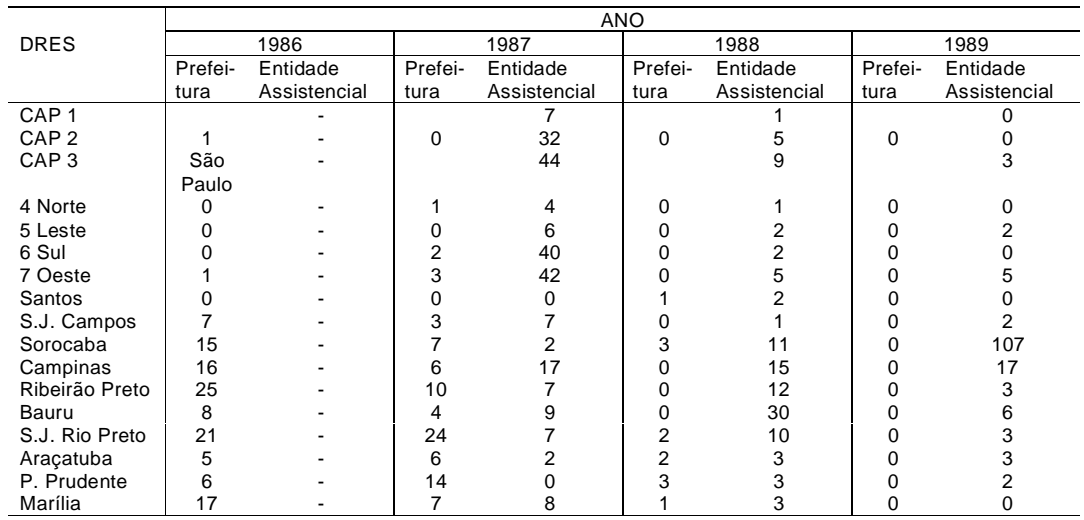

Fonte: Profic/SE. Elaboração NEPP/Unicamp, 1993

${ }^{*}$ Foram fornecidos dados totais 


\section{Tabela 8}

Número de Alunos atendidos pelo Profic, Tipo de Convênio por Divisão Regional de Ensino (DRE)

Estado de São Paulo - 1989

\begin{tabular}{|c|c|c|c|c|c|c|}
\hline \multicolumn{3}{|l|}{ Repasse } & \multicolumn{4}{|c|}{ Convênios } \\
\hline & \multicolumn{2}{|c|}{ Rede Estadual } & \multicolumn{2}{|c|}{ Prefeitura } & \multicolumn{2}{|c|}{ Entidades Assistenciais } \\
\hline & № Escolas & № alunos & № Convênios & № Alunos & № convênios & № Alunos \\
\hline CAP 1 & 5 & 402 & & & 3 & 1.440 \\
\hline CAP 2 & 37 & 4.247 & & & 22 & 9.613 \\
\hline CAP 3 & 20 & 3.245 & & & 21 & 4.177 \\
\hline 4 Norte & 19 & 1.563 & & & 3 & 950 \\
\hline 5 Leste & 47 & 5.115 & & & 8 & 1.667 \\
\hline 6 Sul & 140 & 67.898 & 2 & 1.003 & 39 & 7.903 \\
\hline 7 Oeste & 26 & 1.970 & 2 & 705 & 44 & 10.381 \\
\hline $\begin{array}{l}\text { Subtotal } \\
\text { COGSPP }\end{array}$ & 294 & 84.440 & 4 & 1.708 & 140 & 36.131 \\
\hline Santos & 25 & 1.798 & 1 & 600 & 2 & 185 \\
\hline S.J. Campos & 82 & 4.866 & 5 & 2.995 & 8 & 1.721 \\
\hline Sorocaba & 55 & 3.289 & 15 & 12.233 & 13 & 3.294 \\
\hline Campinas & 51 & 3.216 & 15 & 15.383 & 47 & 10.155 \\
\hline R. Preto & 50 & 5.107 & 23 & 11.052 & 24 & 4.911 \\
\hline Bauru & 34 & 2.640 & 8 & 4.000 & 17 & 3.417 \\
\hline S.J.R. Preto & 100 & 7.638 & 31 & 9.098 & 20 & 3.706 \\
\hline Araçatuba & 47 & 6.071 & 12 & 3.148 & 8 & 3.453 \\
\hline P. Prudente & 71 & 3.817 & 15 & 4.251 & 3 & 120 \\
\hline Marília & 25 & 1.891 & 21 & 10.649 & 8 & 1.727 \\
\hline Registro & 44 & 3.839 & 3 & 1.065 & - & - \\
\hline Subtotal CEI & 584 & 44.172 & 149 & 74.474 & 150 & 32.689 \\
\hline Total & 878 & 128.612 & 153 & 76.182 & 290 & 68.820 \\
\hline
\end{tabular}

Fonte: Profic/SE.

Elaboração NEPP/Unicamp, 1993.

Obs.: Faltam os dados de duas D.E.

Características do processo de implementação, obstáculos, respostas dos agentes envolvidos e dos beneficiários

A natureza e o conteúdo das duas versões do Profic apresentadas, a cultura política e o conjunto de interesses vigentes no ambiente da Secretaria de Educação, bem como a particular conjuntura política no estado de São Paulo determinariam as características do processo de implementação do Programa.

Cabe de início ressaltar que, desde o final dos anos 70, o ambiente educacional no estado de São Paulo experimentou um intenso processo de politização. O surgimento e a atuação de algumas entidades representativas de categorias de profissionais de educação (professores, supervisores, diretores) inauguraram a participação des- 
ses novos atores, através de movimentos corporativos, na arena decisória, embora seja necessário admitir uma baixa capacidade de influência na formulação de políticas e programas para essa área. Entretanto, não se pode negar que sua presença e, freqüentemente, sua intensa atuação têm contribuído para a seleção de estratégias de implantação, resultando em longos processos de discussão, dado o seu caráter menos decisório e mais obstrutivo.

O lançamento do Profic, consubstanciado em dois decretos, encontrou resistências do professorado organizado. Essas resistências foram entendidas pelos organizadores do programa como tentativas do professorado de esconder as falhas da escola existente e de manter seus interesses corporativos.

No entanto, o padrão descentralizado pelo qual o Profic se implantou, o caráter voluntário de incorporação das escolas estaduais ao regime de tempo integral e a destinação de parte significativa dos recursos a escolas municipais e privadas não propiciaram ao magistério organizado condições de oposição em bloco, como ocorreu no Rio de Janeiro; as críticas permaneceram nas instâncias intelectuais que se preocupavam especialmente com a concepção do programa e as prioridades de atendimento das demandas educacionais da maioria da população. (Cunha 1991, pp. 2 e 3)

As entidades da área da educação e o movimento sindical do magistério sempre tiveram um alinhamento político próximo dos partidos políticos de oposição, o que é perfeitamente compreensível, uma vez que sua atuação mais intensa coincide com o crescimento dos movimentos pela redemocratização, nos anos 80 . Isso ficou bastante evidente no lançamento do Profic num ano em que houve disputa acirrada pelo governo do estado. A apresentação do Profic, às vésperas das eleições, em agosto de 1986, mobilizou a comunidade educacional. Foi um dos poucos programas educacionais com capacidade de mobilização de opiniões, durante a década de $1980 .^{26}$

A mobilização contrária ao Projeto contou com a participação da maioria das associações de profissionais da área da educação do estado, que atuaram em bloco e de modo organizado para caracterizar o Programa como "megalomaníaco, politicamente reacionário, pedagogicamente inconsistente e apresentando fatos já negados em trabalhos científicos". (Folha de S. Paulo 6/6/1986) 
Essa forte mobilização, ao que tudo indica, impediu que a socialização das informações e sua discussão fossem utilizadas como estratégia de formação do consenso relativo aos conteúdos básicos e princípios orientadores do Programa, logo na primeira fase. Se a idéia inicial era de implantar o Profic na rede estadual de ensino e por meio de convênios com prefeituras e entidades assistenciais, a reação, que pode ser classificada de desproporcional, desviou a procura de adesões para fora do âmbito da própria Secretaria. A equipe responsável pela implantação inicial do projeto qualificou as críticas como políticas - dado o momento eleitoral - e ideologicamente comprometidas - dado o tipo de fundamentação teórico-metodológica utilizada.

Dentro desse raciocínio, as prefeituras e as entidades assistenciais pareciam - e efetivamente foram - um campo fértil para a expansão inicial do Programa, pois, além de vivenciarem necessidades cotidianas de busca de recursos, revelaram uma certa imunidade à discussão política e ideológica - muito presente nos movimentos dos profissionais de educação ligados ao Estado - e que já havia impregnado as tentativas de implantação no interior da rede estadual de ensino. Esse dissenso marcaria profundamente o processo de implementação do Profic.

No tocante às prefeituras, a implementação do Programa revelou muita simplicidade e uma notável ausência de procedimentos burocráticos. ${ }^{27}$ Ademais, é importante ressaltar que as prefeituras e as entidades assistenciais, além de representarem uma demanda reprimida por recursos para suas atividades educacionais e assistenciais, reuniam uma excelente capacidade de organizar recursos preexistentes. Como ressaltou o professor Pinotti:

Não há prefeito que não conheça espaços ociosos em seu município. As entidades de bairro, os salões paroquiais, as entidades religiosas, católicas, espíritas, protestantes etc., as próprias pessoas físicas têm, às vezes, locais desalugados há anos, ou não têm interesse em alugá-los. Enfim, não existe falta de espaço físico. (Pinotti 1993) ${ }^{28}$

Do ponto de vista dos recursos humanos, a solução foi encontrada em uma resolução do Secretário autorizando o pagamento de professores. 
Então, com esta resolução contratavam-se estes novos docentes e pagavam-se diretamente docentes para a rede de ensino, para as prefeituras, que as Delegacias afastavam e pagavam em função da resolução. ${ }^{29}$ Era dinheiro do Tesouro do Estado para o pagamento de professores. A Secretaria ainda dava um auxílio que era dinheiro do QESE, muito pequeno, quando eram as prefeituras e um adiantamento para o diretor da escola comprar comida, quando a escola não tinha um prefeito que tivesse essa sensibilidade. A alimentação nas escolas tinha sido municipalizada na época do [Governador Franco] Montoro. Assim, a maioria já tinha cozinheira contratada pelo município (...). E a Secretaria dava auxílio para essa alimentação, para o prefeito. Dava mais professores e mais dinheiro do QESE para as prefeituras complementarem a alimentação. (Tojal 1993)

Os dados disponíveis mostram que no ano de 1991, quando o Programa já entrava em declínio, havia 800 professores da rede estadual de ensino alocados em suas atividades. Estavam distribuídos por 244 unidades, atendiam a 1.591 turmas de alunos, ou seja 42.289 crianças. Havia então uma média de 3,27 professores por unidade de Profic, trabaIhando dois turnos, atendendo 26,5 alunos por classe, em média.

Essas informações, embora limitadas a um único ano, demonstram que a Secretaria, ao assumir a maior parte dos encargos de pessoal, garantia a implementação do programa às prefeituras. $O$ mecanismo era semelhante para os convênios com entidades assistenciais. Houve, também, nos dois casos, contratação de professores e técnicos para as atividades. Como estas eram muito variadas de unidade para unidade, ocorriam casos de contratação de marceneiros, costureiras etc., desde que as atividades programadas requisitassem tais serviços. Em geral, os professores eram contratados com recursos repassados pela Secretaria de Educação às prefeituras e às entidades assistenciais. No que tange à rede estadual de ensino, os recursos eram repassados ou à direção da escola ou às Associações de Pais e Mestres (APMs) que, em muitos casos, desempenharam um papel aditivo na execução do programa.

Se o Profic, do ponto de vista de seu processo de implementação, pode ser periodizado em três fases, ${ }^{31}$ pode também ser compreendido em dois campos distintos. De um lado, no primeiro campo, com extremas dificuldades políticas, o mutual partizan adjustment revelava-se praticamente impossível, com alta propensão ao conflito, envolvendo, de uma 
parte, os propositores do Programa (Gabinete do Secretário) e de outra, membros da alta burocracia da Secretaria, associações dos profissionais da educação internas e externas à Secretaria e, em alguns momentos, órgãos de imprensa. A conjuntura político-eleitoral na qual se deu a implantação do programa, as subculturas políticas em confronto fazem supor que se estabeleceu um jogo não somente referido a uma política específica, mas a outro campo, da metapolicy, ou seja, um âmbito no qual se definem e redefinem as chaves de leitura de uma política pública, sua localização numa arena política possível, a manutenção de vínculos com as bases, e a capacidade de representar preferências. (Regonini 1985)

Em outras palavras, a implantação do Profic não era o único jogo sobre o tapete, pois se imagina que também se resolviam naquele momento problemas vinculados a outras arenas políticas. Com o esfriamento da conjuntura e com o relativo sucesso da implantação inicial por prefeituras e entidades assistenciais, bem como as mudanças de estratégias provocadas pelas mudanças de atores, a porta de entrada para a implantação na rede estadual de ensino iria, pouco a pouco, tornando-se mais aberta.

A propensão ao consenso e de ajustamento de interesses dos atores envolvidos, no que diz respeito à interação com prefeituras e entidades, sempre foi muito maior. Como já foi apontado, essas instituições tinham interesses claros, sempre estiveram mobilizadas na busca de fundos do governo do estado e dispunham de alguma experiência na mobilização de recursos comunitários. Não se pode deixar de registrar que, ao final do governo de Franco Montoro, o partido do governo (PMDB) detinha a maior parte das prefeituras do estado de São Paulo, e a maior parte de seus prefeitos estava envolvida na campanha sucessória. Tal fato, embora não tenha tido uma importância crucial na aceitação do Programa, teve, sem dúvida, um peso relativo considerável.

Uma das críticas levantadas contra a forma de implementação do Profic foi a presença do clientelismo. Essa prática, de fato, ocorreu. Muitos prefeitos utilizaram, nesse sentido, os mecanismos de remoção e transferência de professores para - por meio do Programa - atender seus eleitores e correligionários. Deve ser ressaltado, no entanto, que as práticas clientelistas não são um atributo específico do Profic. São, muito mais, um traço na cultura política brasileira, com especial arraigamento - sem exceção de governos ou secretários - na Secretaria de Educação do estado de São Paulo.

O fato de o Profic ter sido um programa com adesões voluntárias fez com que a resposta dos agentes sempre tenha sido positiva. Dife- 
rentemente de outras políticas da Secretaria que prescreviam um engajamento compulsório, esse projeto revelava um alto grau de participação dos agentes envolvidos. Entre os entrevistados, essa visão foi praticamente unânime. Os planos de atividades, bem como a decisão em participar do Profic, nas unidades estaduais envolvidas com o Programa, deveriam ser aprovados pelos Conselhos de Escola. ${ }^{32}$

Entre 1987 e 1989, nota-se uma clara preocupação em formular uma proposta pedagógica para o Profic. ${ }^{33}$ Tal preocupação parecia ter dois fundamentos: em primeiro lugar, a forma inicial de implementação não previa instrumentos de controle e avaliação rígidos. Assim, a coordenação do Programa, depois de 1987, procurou - com a publicação de documentos de orientação - disciplinar, ou pelo menos ordenar as atividades, bem como vislumbrar uma possibilidade de avaliá-las. (Lima 1989, Mendes Júnior 1991) Essa nova orientação significou, em segundo lugar, uma tentativa de aculturação do Profic ao ambiente da Secretaria de Educação. Aos poucos, a idéia de escola-proteção vai dando lugar a atividades mais convencionais e mais compatíveis com o clima cultural de uma instituição complexa, fragmentada e altamente burocratizada. Na verdade, essa domesticação foi decisiva para a continuidade e a ampliação do Programa na rede estadual de ensino.

A partir de 1990, inicia-se a fase do Profic que culminará na extinção do programa. Como pode ser verificado na tabela 6 , o número de atendimentos decresce de forma abrupta e sem possibilidade de recuperação. Embora os dados refiram-se apenas à rede de ensino estadual, a partir de 1991 essa afirmação pode ser estendida para prefeituras e entidades assistenciais, em relação às quais deixam de existir dados consistentes.

O declínio do Profic deve-se a alguns fatores. No caso das entidades assistenciais, a tendência já se manifestara pela aplicação do dispositivo constitucional que não permitia o repasse de recursos financeiros para instituições do gênero. Quanto às prefeituras, alguns fatores ajudam a formular uma hipótese para explicar a queda na sua participação. Um deles refere-se à proibição de afastamentos de professores da rede de ensino para prestarem serviços em outros órgãos. Esse fator pode ter reduzido muito o interesse dos prefeitos em aderir ao Programa, uma vez que as despesas com pessoal representavam o item mais pesado na alocação de recursos financeiros. Um segundo fator pode estar localizado nas sucessivas mudanças de orientação política na Secretaria, decorrentes de mudanças de Secretários. 
Foram três Secretários em 19 meses de governo. Um terceiro fator, importante, podem ter sido as mudanças no governo estadual ocorridas em 1991. O novo governo ${ }^{34}$ propôs uma reforma no ensino público, sem deixar lugar ou oportunidades para outros programas considerados não prioritários.

A extinção do Profic, no final de 1993, conseqüência da política educacional implementada em 1991, deveu-se a razões de ordem técnica e também política. Depois de uma prolongada greve de professores, no final do mesmo ano, que teve como objeto principal a recomposição dos salários do professorado e de outras categorias profissionais (com grande impacto nas despesas da Secretaria de Educação), foi tomada a decisão de extinção de todos os programas que não respondessem ao requisito de atendimento universal no interior da rede de ensino.

\section{Controle, monitoramento e avaliação}

Da perspectiva formal, ao implantar o Profic em 1986, a Secretaria de Educação recomendava a produção de um plano de trabalho, instrumento essencial para as atividades de controle, acompanhamento e avaliação do Programa por parte das Delegacias de Ensino. Nesse sentido, sugeria que as unidades escolares realizassem registros das atividades - em instrumentos como diário de classe, fichas individuais dos alunos e relatórios (bimestrais, semestrais e anuais) -, bem como organizassem reuniões para avaliação do programa.

Entretanto, os depoimentos dos membros das equipes técnicas - do Gabinete do Secretário de Educação (1986/1989) e das Coordenadorias de Ensino - COGSP e CEI (1990/1993) - evidenciaram a absoluta ausência de instrumentos que possibilitassem o controle, o acompanhamento e a avaliação do Profic durante esses anos. Nesse sentido, os planos de trabalho realizados pelas escolas - estaduais, assistenciais ou municipais chegavam até a Delegacia de Ensino e percorriam as várias instâncias da estrutura da Secretaria - Divisão Regional de Ensino, Coordenadoria de Ensino e Gabinete (equipe de coordenação central) -, sem receber em nenhum deles uma avaliação das propostas, das metas e dos resultados alcançados pelas unidades escolares. ${ }^{35}$ O Programa foi extinto ao término do ano letivo de 1993, sem ter sido objeto de uma avaliação mais profunda de seus resultados. 
Em resposta às propostas de interrupção do Programa, durante as várias gestões, a equipe central de coordenação do Profic elaborou um instrumento de avaliação de sua implementação. (Mendes Júnior 1991) O objetivo dessa avaliação, realizada em 1990, era justificar a permanência do Programa para o novo Secretário de Educação. ${ }^{36}$

A avaliação foi elaborada a partir de questionários sem refinamento técnico enviados às escolas, com a preocupação de "captar informações sobre o Profic, sua eficiência e, sobretudo, sua eficácia em termos de impacto no processo ensino-aprendizagem" (Mendes Júnior 1991, p. 7) As questões abarcaram: a) informações sobre a implantação; b) diagnóstico socioeconômico e cultural dos alunos; c) objetivos e adequação de recursos do programa; d) adequação da proposta educacional da escola ao proposto pelo programa; e) operacionalização da proposta; f) sistema de acompanhamento, controle e avaliação. Das 1.234 unidades educacionais que ao final de 1989 mantinham o Profic, 791 responderam aos questionários. As Delegacias e as Divisões Regionais de Ensino participaram das tabulações. O resultado desse trabalho não foi utilizado por nenhum dos órgãos centrais ou intermediários envolvidos na implementação do Profic.

A preocupação do questionário, no que se referia ao controle, ao acompanhamento e à avaliação, se circunscreve apenas à identificação de instrumentos de registro sobre os alunos. Parece haver confusão teórico-metodológica sobre a concepção de avaliação de programas educacionais. Assim, o relatório conclui que há registros sistemáticos nas unidades escolares sobre a implementação do programa.

O mesmo relatório analisou os indicadores de eficácia do programa, comparando, em 1989, os índices de evasão e retenção dos alunos das escolas com os alunos que participavam do Profic. Os resultados indicavam que a taxa de evasão entre os alunos do Profic era menor do que a taxa de evasão no conjunto das escolas em $82,3 \%$ das unidades pesquisadas. Da mesma forma, em $84,5 \%$ das escolas, o índice de retenção era menor entre os alunos do Profic. Os professores (97\%) afirmavam que houve melhoria no rendimento escolar dos alunos inscritos no Profic. Do ponto de vista das relações das crianças com seu grupo, metade dos professores informavam que houve melhoria, ficaram mais sociáveis $(40 \%)$ e tornaram-se mais bem-humoradas (76\%). As crianças (83\%) do Profic apresentaram empenho na realização das tarefas escolares, bem como aumentaram a capacidade de tomar iniciativas (82\%) e de se expressarem (90\%). 
Se o relatório apresentou resultados bastante favoráveis quanto ao desempenho dos alunos inseridos no Programa, apresentou também as dificuldades em consolidá-lo. As questões de infra-estrutura do Programa apareceram com freqüência: falta de material escolar, recursos financeiros (chegavam sempre tardiamente) e inadequação ou falta de espaço físico; bem como a insuficiência de orientação técnica para desenvolvimento do programa, o isolamento em relação aos órgãos públicos, a falta de participação comunitária e a demanda reprimida.

Essa avaliação, ainda que o próprio grupo que a organizou afirme ter inconsistência, não foi objeto de continuidade e levou ao estabelecimento de estratégias de intervenção. A entrevista com a delegada de ensino confirmou a não-existência de instrumentos de acompanhamento e avaliação do Programa por parte dos supervisores. Não foi possível analisar a viabilidade pedagógica e financeira pela ótica dos implementadores, dada a ausência de informações disponíveis sobre os custos e sobre a qualidade educacional do Programa.

\section{Resultados e problemas}

Dentro da perspectiva analítica adotada, a avaliação de resultados e problemas não passou exclusivamente pela consecução dos objetivos, nem pela elaboração de um elenco de acertos e erros, de sucessos e fracassos na implementação de uma política pública. Nesse sentido, a avaliação deve ser eminentemente analítica, envolvendo, antes de um julgamento global, o exame parcial dos vários aspectos envolvidos.

Do ponto de vista da concepção geral do Profic, que propunha quatro projetos, podemos afirmar que apenas aqueles que se localizavam na área exclusiva da Secretaria de Educação foram implantados. Os demais - Formação integral da criança nos dois primeiros anos de vida e Atendimento ao menor abandonado -, por razões já apontadas, não foram ativados. Seja porque a concepção inicial de atividade escolar que os embasava fosse extremamente ampla, e, nas condições sociopolíticas vigentes na Secretaria, era inexeqüível, seja porque os mecanismos de cooperação interinstitucional previstos (ação conjunta de várias Secretarias de Estado) fossem ineficazes, esses dois programas não chegaram a se concretizar. 
Ainda nessa perspectiva dos objetivos mais gerais e da fundamentação filosófica, os dois programas que foram implementados - Formação integral do pré-escolar e Formação integral do escolar - também não conseguiram transformar conceitualmente a escola. Entretanto, o objetivo prático que era o aumento do tempo de permanência da criança na escola, senão totalmente, foi largamente atingido. $O$ alcance parcial desse objetivo deve-se, em parte, ao próprio abandono daquela concepção inicial. Nesse sentido, o expressivo número de 503.247 crianças, num universo focalizado de cerca de 1.279 .839 crianças indigentes $e$ pobres, na faixa etária de 7 a 14 anos, matriculadas na rede de ensino escolar é auto-explicativo.

Por outro lado, as poucas pesquisas e avaliações disponíveis sobre a melhoria das condições de ensino e aprendizagem trazidas pelo Profic também mostravam resultados positivos. A falta de dados sobre os custos não permite uma avaliação segura sobre a eficácia comparada do Profic. Pode-se afirmar, no entanto, que o estabelecimento de parcerias com o terceiro setor e com as prefeituras revelou muita criatividade no aproveitamento de recursos humanos e materiais preexistentes, bem como na sua utilização de modo renovado.

Esse fato revelou uma forma nova de inserção institucional para programas do gênero. O caráter voluntário das adesões e a forma desburocratizada de estabelecimento das parcerias e gestão dos convênios também foram avaliados - seja na literatura, seja pelos agentes envolvidos - como altamente positivos. Entretanto, essa avaliação deve ser relativizada, uma vez que a adesão voluntária já parte de um pressuposto favorável ao projeto.

O processo de implementação, em meio a grandes resistências e, ao mesmo tempo, a adesões ardorosas, revelou que o custo de implantação de programas destoantes dos padrões convencionais de instituições complexas e altamente burocratizadas é muito alto. Esse Programa não contou com boa estratégia para quebrar resistências e conquistar a burocracia. As resistências estruturais aliadas às conjunturas políticas específicas foram barreiras muito fortes para a implantação do Profic.

Por outro lado, a busca de estruturas alternativas para a implantação do programa - tais como prefeituras e entidades assistenciais revelou-se de grande validade na implementação, pois possibilitou a utilização direcionada de demandas preexistentes, bem como de mecanismos políticos tradicionais. 
No caso específico do Profic, a estratégia inicial de obtenção de consenso elevou a propensão de conflito já existente no interior da Secretaria, criando rejeições que, embora tenham sido contornadas na medida em que o programa se adaptou à cultura institucional da Secretaria, permaneceram difusas, porém atuantes, durante seu tempo de duração.

\section{Notas}

1. No âmbito municipal houve experiências recentes (1989/1992) de prolongamento da jornada diária dos alunos: Porto Alegre (RS) ampliou de 4 para 6 horas diárias o tempo de permanência das crianças na escola; ljuí (RS) ampliou o tempo de permanência diária de crianças e adolescentes considerados grupos populacionais vulneráveis; Conchas (SP) implantou a Escola Comunitária em período integral e seriação assistemática para crianças de rua. São alguns exemplos de intervenção municipal na linha proposta pelo Profic.

2. Entende-se por terceiro setor o segmento da iniciativa privada.

3. Nesse ano estavam matriculadas 6.282 .262 crianças no ensino básico público e privado, assim distribuídas: 759.029 em educação pré-escolar e 5.523.233 em ensino fundamental. O Profic atingia 31,9\% dos pré-escolares e $4,7 \%$ dos alunos do ensino fundamental. É importante registrar que $79,1 \%$ das matrículas no ensino fundamental, em São Paulo, eram na rede de ensino estadual.

4. Professor-doutor José Aristodemo Pinotti (16/5/1986 a 15/3/1987); doutor Chopin Tavares de Lima (16/3/1987 a 7/8/1989); professor-doutor Wagner Gonçalves Rossi (8/8/1989 a 9/1/1990); professor-doutor José Goldemberg (10/1/1990 a 15/3/1990); professor-doutor Carlos Estevam Martins (29/3/ 1990 a 14/3/1991); Fernando Gomes de Morais (16/3/1991 a 2/9/1993) e professor-doutor Carlos Estevam Martins (10/9/1993 a 31/12/1994).

5. Das quais o trabalho de Ferretti et alii (1991) realiza um excelente "estado da arte".

6. Referimo-nos ao relatório final - Estudos básicos para definição do tipo de atendimento diferenciado - bem como aos cinco relatórios preliminares, de agosto do mesmo ano.

7. Essas matrículas estavam assim distribuídas: $9 \%$ em pré-escolas estaduais; $69 \%$ nas municipais; $22 \%$ na rede privada de ensino.

8. Nesse ano, o número de municípios do estado era de 572 , o número de escolas da rede de ensino chegava a 5.502, atendendo 4.209 .947 estudantes matriculados. 
9. As entrevistas realizadas pelo NEPP com técnicos das equipes dos órgãos centrais, com a delegada de ensino de São Miguel Paulista e a diretora da EEPG Anne Frank também apresentaram estes como os motivos para a inserção da rede estadual no Programa.

10. Especialmente quando se considera o fato de ter sido iniciado no último semestre do governo Franco Montoro, num momento em que a sucessão estadual ainda não estava definida.

11. Esses dois projetos não foram implantados porque escapavam aos objetivos da Secretaria de Educação do Estado. Como não havia uma coordenação inter-Secretarias que atribuísse competências e responsabilidades em relação ao Programa, ambos ficaram sem implantação.

12. Embora no conjunto das experiências estaduais tenha prevalecido a indicação da professora da classe, havia exceções. O Profic instalado no Parque Ecológico do Tietê foi uma delas. Os pais dos alunos não indicados pelas professoras solicitavam da diretora da escola a inclusão de seu filho no programa ou então "matriculavam" a criança diretamente no Parque Ecológico. A EEPG Anne Frank chegou a ter $80 \%$ de seus alunos de $1^{\text {a }}$ a $4^{\text {a }}$ série participando do Profic no Parque Ecológico por demanda dos pais. Informações obtidas através do depoimento da diretora da escola ao NEPP, 27/1/1994.

13. Esse estudo foi realizado entre outubro de 1993 e fevereiro de 1994.

14. O ensino público fundamental (regular ou supletivo) possui como fonte adicional de financiamento a contribuição social do salário-educação recolhida das empresas (a alíquota era de 1,4\% da folha de contribuição, recolhida mensalmente ao lapas). As empresas podem também optar pela manutenção direta de escolarização. A arrecadação total do salário-educação, deduzidas as despesas do órgão arrecadador, é dividida em duas partes: Quota Federal e Quota Estadual. Os recursos - federal e estadual - são transferidos aos municípios na forma de auxílio para projetos municipais ou intermunicipais.

15. Depoimento da professora Maria Lúcia Vieira Alves Andreotti Tojal, Chefe de Gabinete do então Secretário de Educação do Estado, professor-doutor José Aristodemo Pinotti, em 16/12/93.

16. As séries iniciais do ensino fundamental, desde 1984, têm sido objeto de reformulações. Assim, no segundo ano do governo Montoro (1984) foi instituído o Ciclo Básico, que procurou otimizar o período de alfabetização das crianças, buscando "maior flexibilidade na organização curricular quanto a agrupamento de alunos, utilização de estratégias adequadas, revisão de conteúdos programáticos e mudanças nos critérios de avaliação". No ano seguinte (1985), o Estatuto do Magistério (LC 444/85) reorganizou a jornada de trabalho docente dos professores que atuavam nas quatro séries iniciais, diminuindo o tempo de permanência da crianças na escola (de 20 horas relógio semanais passou para 20 horas-aula, com 50 
minutos cada). Em 1988 (segundo ano do governo Quércia) essa situação foi revertida, em parte, com a implementação da Jornada Única de Trabalho Docente e Discente no ciclo básico. Os alunos passaram a ter 30 horas-aula semanais, sendo 26 horas-aula com o professor polivalente e 4 com professores habilitados em educação física e educação artística. Em 1991 (primeiro ano do governo Fleury), foi implementada a Reforma do Ensino Público Paulista - "Escola Padrão" - que estendeu a Jornada Única para todos os alunos das quatro séries iniciais do ensino fundamental matriculados em escolas participantes do Projeto "Escola Padrão".

17. Os Planos de Trabalho Anuais (PTAs) são referentes aos anos de 1990, 1991 e 1992.

18. Em uma avaliação posterior, tanto o Secretário Pinotti quanto membros do seu gabinete de implantação do Profic referiram-se a seus resultados da cooperação com outras secretarias de Estado como "pequenos", embora não tivessem ocorrido "boicotes". Tudo indica que uma única experiência do Profic, que resultou num alto nível de cooperação inter-secretarial, foi a do Parque Ecológico do Tietê, já referido em nota neste texto.

19. Entrevista concedida ao NEPP em 16/12/93.

20. Entrevista concedida ao NEPP em 16/12/93.

21. Exemplo desse processo pode ser verificado no Parque Ecológico do Tietê, zona leste da capital, bairro de São Miguel Paulista, subordinado à Secretaria de Recursos Hídricos, Saneamento e Obras do Estado. Nesse parque, a Secretaria do Menor, a partir de 1987, desenvolveu o programa "Clube da Turma" destinado às crianças e aos jovens oriundos de famílias de baixa renda. O programa contava com o envolvimento de diferentes Secretarias, dentre as quais a SEE, que fornecia os professores. O Profic atuava junto com o "Clube da Turma". As escolas e as famílias inscreviam as crianças para complementação do período escolar no Parque Ecológico. Havia seis ônibus que percorriam as escolas, levando as crianças para as atividades esportivas, de enriquecimento curricular, artísticas, de educação ambiental no período oposto ao das aulas nas escolas. A Secretaria do Menor oferecia merenda e transporte. Com o término do Profic, os professores da rede de ensino estadual foram retirados do programa, embora as atividades continuassem para as inscrições voluntárias das famílias. (Entrevista concedida ao NEPP, em 27/1/94, pela diretora da escola Anne Frank, participante do Profic, assim como visita da pesquisadora ao Parque Ecológico na mesma data).

22. Através da Resolução SE 159.

23. Os planos de trabalho de escolas do interior do estado analisados: EEPG Orlando da Costa Telles (Ibaté), EEPG Deputado Leônidas Pacheco Ferreira (Bocaina) e EEPG Valeriano Fonseca (Guaraçaí). 
24. A Constituição do Estado de São Paulo (1989), no seu artigo 246, define que "A eventual assistência financeira do Estado às instituições filantrópicas, comunitárias ou confessionais, conforme definidas em lei, não poderá incidir sobre a aplicação mínima prevista no artigo 255". E o artigo 255: "O Estado aplicará, anualmente, na manutenção e no desenvolvimento do ensino público, no mínimo $30 \%$ da receita resultante de impostos, incluindo recursos provenientes de transferências".

25. Entrevistas concedidas ao NEPP pelos membros da equipe de coordenação central do Profic (1986 a 1989) em dezembro de 1993.

26. O debate em torno da reformulação da legislação educacional teve grande impacto no campo educacional. Em termos de proposta de programa governamental, o Profic conseguiu mobilizar um maior espectro de opiniões na área educacional.

27. Ver "Inserção institucional e esquemas de gestão", neste texto.

28. Entrevista concedida ao NEPP em 16/12/93.

29. O depoimento refere-se à resolução SE 254/86.

30. Entrevista concedida ao NEPP em 16/12/93.

31. Ver "A gestão institucional e os esquemas de gestão", neste trabalho.

32. Os planos de trabalho das escolas analisados nesta pesquisa estavam acompanhados das atas com as deliberações do Conselho de Escola. Esse colegiado possui poder deliberativo desde 1983, é composto por pais e alunos $(50 \%)$ e professores e funcionários $(50 \%)$ e presidido pela direção da escola (membro nato). Pesquisas realizadas pelo Núcleo de Estudos em Políticas Públicas (NEPP) e pela Ação Educativa têm evidenciado a pouca inserção desses colegiados na gestão das unidades escolares. Portanto, inferimos que as atas das reuniões dos Conselhos de Escolas apenas aprovavam o plano de atividades das escolas.

33. Entrevista concedida ao NEPP em 12/93, por Hélio Amorim, coordenador da equipe central no período de 1987 a 1989.

34. Governador Luiz Antônio Fleury e Secretário de Educação, Fernando Morais.

35 Não há relatórios ou avaliações cobrindo todo período de existência do Profic (1986/1993). A primeira etapa da implantação (1986) conta com um relatório oficial assinado pela Secretaria de Educação. Na segunda etapa (1987/1989) há relatório formado pela junção de vários documentos preliminares. E, na terceira etapa (1990/1993), inexistem relatórios, mesmo parciais.

36 Era final do mandato do governador Orestes Quércia e o Secretário de Educação era o professor Carlos Estevam Martins (29/3/1990 a 14/3/1991). 


\section{Children at school? Child Integral Upbringing Program}

ABSTRACT: This article analyses a public policy that was implemented in São Paulo, Brazil, between 1986 and 1993. This public program, called PROFIC- "Programa de Formação Integral da Criança"- sought to extend the permanency time of poor children at school and expand the conditions to their better performance in learning. The authors chose an "incrementalist" approach and used classical concepts of policies analysis, such as "actors", "policy community", "policy network", "partizan mutual adjustment", among others. At the same time they tried to consider the policies conditions that then involved this policy-making process.

\section{Bibliografia}

ANDE. Boletim Informativo. Edição especial. São Paulo: ano VI, № 14, jul. 1986a.

ANDE. "Profic: Formação integral da criança ou assistencialismo". São Paulo: ano 5, no 11, 1986b, pp. 56-61.

CUNHA, Luiz Antônio. Educação, Estado e democracia no Brasil. São Paulo/Rio de Janeiro: Cortez, Eduff e Flacso, 1991.

DURHAN, Eunice R. "Uma política para a Secretaria de Educação do Estado de São Paulo”. São Paulo: SEE, mar. 1990. (mimeo.)

FECAMP. "Estudos básicos para definição do tipo de atendimento diferenciado". Campinas: Fecamp/IE, 1985. (mimeo.)

FERRETTI, Celso João (coord.). "Estudo exploratório sobre experiências de extensão do período diário de atendimento educacional para alunos da rede pública de ensino em São Paulo". São Paulo: Fundação Carlos Chagas, 1991. (mimeo.)

FERRETTI, Celso João et al. "Escola pública em tempo integral: O Profic na rede estadual em São Paulo". Cadernos de Pesquisa. São Paulo: no 76 , fev. 1991, pp. 5-17.

LIMA, Chopin Tavares de. Educação em São Paulo: Diretrizes básicas do programa de governo. São Paulo: FDE, 1987a.

Educação: Nosso desafio. São Paulo: FDE, 1987b. 
LIMA, Chopin Tavares de et al. Profic: Diretrizes e ações. São Paulo: FDE, 1987c.

. Profic: Educação integral em construção. São Paulo: FDE, 1989.

MENDES JÚNIOR, Carlos Luiz. "Relatório preliminar de uma avaliação do Profic - ano-base 1989". São Paulo: SEE, mar. 1991. (mimeo.)

NEPP. "A situação do menor no Estado de São Paulo" (Relatório final). Campinas: convênio Funabem/NEPP/Unicamp, jan. 1990.

PARO, Vítor H. et al. "A escola pública em tempo integral: Universalização do ensino e problemas sociais". Cadernos de Pesquisa. São Paulo: no 65, maio, 1988, pp. 11-20.

REGONINI, Gloria. "Le politiche sociali in Italia: Metodi di analisi". RISP, ano IV, dez., 1985, pp. 335-377.

."L'analisi delle politiche pobliche". In: PANEBIANCO, A. L'analise della politica. Bolonha: II Mulino, 1989.

SAMARTINI, Luci Silva. "O programa de formação integral da criança Profic: Um espaço na escola pública". Dissertação de mestrado. São Paulo: PUC, 1988.

SÃO PAULO (Estado). Constituição do Estado de São Paulo. São Paulo: Imesp, 1989.

SÃO PAULO (Estado) Secretaria de Educação. A implementação do ciclo básico nas escolas estaduais de São Paulo - avaliação do primeiro ano. São Paulo: SEE, 1985.

. "Profic - Programa de formação integral da criança". São Paulo: SEE, 1986a. (mimeo.)

"Programa de formação integral da criança - Profic". Relatório. São Paulo: SEE/ ATPCE/ CIE, 1986b.

Profic - avaliação de um projeto. São Paulo: SEE/CENP, 1992.

(Série: Avaliação Educacional)

SILVA, Rose Neubauer da et al. "O descompromisso das políticas públicas com a qualidade de ensino". Cadernos de Pesquisa. São Paulo: $n^{\circ} 84$, fev. 1993, pp. 5-16.

TENCA, Ana Maria. "Documento preliminar de avaliação do Profic - 1990". São Paulo: SEE, 1990. 